Emir. J. Food Agric. 2007. 19 (1): 13-21

http://www.cfa.uaeu.ac.ae/research/ejfa.htm

\title{
Use of selected agro-industrial biomass for enhancing seed nitrogen, ash and crude protein quality of Amaranthus viridis. L
}

\section{E. I. Moyin-Jesu}

\author{
Agronomy Department, Federal College of Agriculture, \\ Akure, Ondo State, Nigeria
}

\begin{abstract}
The effect of selected agro-industrial biomass of woodash, spent grain, cocoa husk, rice bran and sawdust applied solely and supplemented with goat, pig and poultry manure to improve on the seed nitrogen, ash and crude protein quality of four crops of Amaranthus was investigated at Akure in the rainforest zone of Nigeria. The 22 treatments were applied at 6t/ha a.i with a reference treatment (400 kg/ha NPK 15-15-15) and a control treatment, replicated four times and arranged in a randomized complete design. The results showed that these biomasses increased the seed $\mathrm{N}$, ash and crude protein of amanranthus significantly $(\mathrm{P}<0.05)$ compared to the control treatment. The supplement of woodash, rice bran, spent grain and sawdust with goat, pig and poultry manure increased consistently the seed $\mathrm{N}$ and crude protein when compared to their sole forms. The sole and supplemented agro-industrial biomass had higher values of amaranthus seed ash than NPK except that of seed $\mathrm{N}$ and crude protein. Cocoa husk treatment had the best value of seed $\mathrm{N}(3.41 \%)$ followed by woodash (3.17\%), spent grain (1.54\%), sawdust $(1.05 \%)$ and rice bran $(0.14 \%)$ respectively. Spent grain gave the highest value of amaranthus seed ash (10.44\%) followed by woodash $(10.04 \%)$, cocoa husk $(6.44 \%)$, rice bran $(5.93 \%)$ and sawdust $(5.71 \%)$. Finally, the sole and supplemented forms of agro-industrial biomass are very fertilizer materials for enhancing seed $\mathrm{N}$, ash and crude protein of amaranthus.
\end{abstract}

Keywords: Agro-industrial biomass, amaranthus, seed N, ash and crude protein.

\section{لمتخدلم بهض المخلف الزراعية والصناعية لنهسينمحتوى البذورمن النيتروجين، الرماد والبروتين الخله في نبلت النعافيفة}

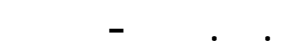

\section{قمم المحاصل، كلية الزراعة الانحاية، لكور، ولاية أونوه، نيجربا}

مُ درلسة تأثير إضافة بعض المخلفلت الزراعية والصناعية من رماد الخشب، الحبوب الميتة، قثور ثمرة الكلكاو، نخالة الأرز ونشارة الغشب بشكل مفرد أو مدعم بمخلفلت الأغنلم والخنازير والدولجن على تمهسن محتوي البذور من النيتروجين والرماد ونوعية البروتين الخلم في نبلت الفطيفة في لكور في الغابلت المطلرة في نيجريا. تمت

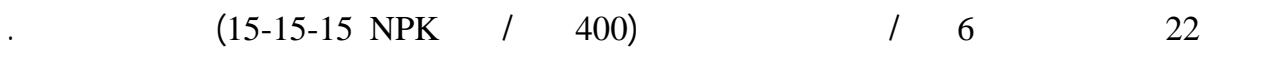
لستخدم التصميم العشوائي الكلمل بأرع مكررت. لُٔلهرت النتائج لن هذه الإضلفت زالت زادت من محتوي البذور للنيتروجين، الرماد والبروتين الخلم بمقارنة بللثاهد. تدعيم رماد القش، الحبوب الميتة، قثور ثمار الكلكاو، نخالة الأرز ونشارة الغشب بمخلفلت الأغنلم و الخنازير والدولجن زادت من محتوي البذور للنيتروجين والبروتين الخهل مقارنة بإضافة المخلفت بشكل مفرد. إضلفة المخلفت بشكل مفرد أو مدعم زاد محتوى البذور للرماد مقارنة مع

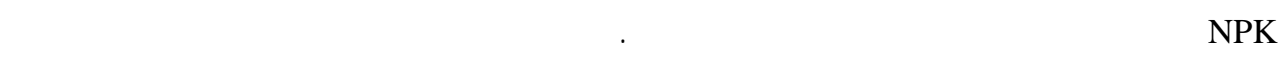

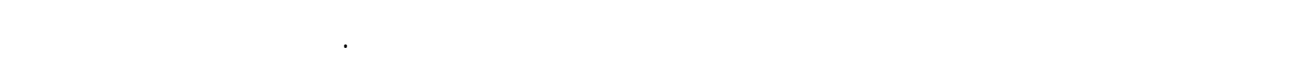

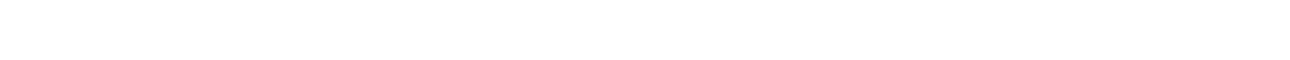

الكلمالت الففلحية: المخلفات الصناعية والزراعية، التطيفة، محتوى البذورمن التتروجين، الرماد، البروتين الخلم. 


\section{Introduction}

Amaranthus (Amaranthus Viridis L) is a crop which had been domesticated by man for years and it is a leafy vegetable that belongs to the family Amaranthaceae. In the tropical region, Amaranthus is often boiled and added to the soup.

Oyenuga (1968) reported that Amaranthus contained Vitamin A 120.00W, Iron 1.40 grammes, 1.90 grammes of protein and water $88.00 \mathrm{ml}$ which are usually deficient in the staple food. These are required for body growth, reproduction and maintenance of health, hence, the demand for Amaranthus by consumers is increasing and they should be produced on sustainable basis to meet the dietary needs of the people.

Despite the nutritional values of amaranthus, its optimum seed yields has not been attained. This is because the crop is produced by the local farmers on intensive basis in small plots on long term basis and this has resulted into decline in its fertility but resource poor farmers can not afford the use of inorganic fertilizers to replenish the depleted soil nutrients because of scarcity and high cost.

The increasing awareness by consumers in Western and tropical countries on the illness such as diabetics, hypertension, cancer and obesity associated with consumption of food produced from using chemical fertilizers, has shifted their focus to safe eating habits by consuming food crop produced by organic fertilizers. The nitrogen, ash and crude protein contents in a food are the measures of its quality consumed by farmers.

Emede et al. (2002) used four rates of poultry manure $5,10,15$, and $20 \mathrm{t} / \mathrm{ha}$ to grow two varieties of Amaranthus cruentus L (NH 84.452 and $\mathrm{NH}$ 84/445) and concluded that $15 \mathrm{t} / \mathrm{ha}$ of poultry manure gave the best fresh leaves weight and number of economic branches of amaranthus. Adebayo and Akoun (2002) used 27 t/ha of pig manure at a population density of 333.333 of Amaranthus cruentus and obtained an increase in the plant height, leaf number, leaf area and leaf yield of 3.0 tonnes/ha.

Ojeniyi and Moyin-Jesu (2000) used $10 \mathrm{t} / \mathrm{ha}$ goat dung to grow amaranthus and reported an increase in the plant height, leaf area, stem girth, number of economic branches and leaf yield of amaranthus. However, the availability of high quantities of these manures required for crop production might be a serious problem and there is need for other sources of organic materials to supplement these quantities of the manures.

Having reviewed literature extensively, there are scarcity of research reports on the use of agro-industrial biomass such as wood ash, rice bran, spent grain, saw dust and cocoa husk applied solely or supplemented with pig, goat and poultry manures on improving the seed nitrogen, ash and crude protein quality of amaranthus.

Therefore, the objective of this paper is to determine the influence of agroindustrial biomass such as wood ash, spent grain, cocoa husk, rice bran and saw dust applied solely or supplemented with animal manure on the seed nitrogen, ash and crude protein quality of four crops of amaranthus.

\section{Materials and Methods}

Source and preparation of organic materials

Cocoa pod husk, wood ash, poultry, goat and pig dropping were obtained from the cocoa farm plots, cassava processing and livestock units of Federal College of Agriculture, Akure.

Rice bran was obtained from the OS6 variety of rice processed at college ricemill. Sorghum based spent grain was 
collected from the International Breweries Ilesa, Nigeria and the saw dust from a nearby saw mill industry at Akure township.

The organic materials were processed to allow decomposition and rapid release of nutrients to crops when incorporated into the soil. The dried cocoa pod husk was ground into powdery form with hammer mill for 30 minutes while the wood ash was sieved mechanically with 2 $\mathrm{mm}$ sieve to remove foreign materials such as charcoal and wood remnant. The rice bran, spent grain and saw dust were each thoroughly wetted with water and composted for six weeks at $70^{\circ} \mathrm{C}$ separately to reduce the high $\mathrm{C} / \mathrm{N}$ ratio.

The poultry, pig and goat manures were stacked separately for one week to allow for quick mineralisation and were placed under shade. These methods of preparation of organic materials were simple and could be readily carried out by farmers.

Chemical analysis of the organic materials used.

Two grammes each of the processed forms of the organic materials used, were analysed. The nitrogen content was determined by Kjedahl method (Jackson, 1964) while the determination of other nutrients such as $\mathrm{P}, \mathrm{K}, \mathrm{Ca}, \mathrm{Mg}, \mathrm{Na}, \mathrm{Fe}$, $\mathrm{Cu}, \mathrm{Zn}$ and $\mathrm{Mn}$ was done using the wet digestion method based on 25-5-5ml of $\mathrm{HNO}_{3}-\mathrm{H}_{2} \mathrm{SO}_{4}-\mathrm{HClO}_{4}$ acids (A.O.A.C., 1970). The K, Ca and Na nutrients were read on flame photometer while $\mathrm{Mg}$ was read on atomic absorption spectrophotometer. The $\mathrm{P}$ content was developed into yellow colouration with vanado-molybdate solution and read on spectronic 20 at 442um. The percentage organic carbon was determined by wet oxidation method through chromic acid digestion (Walkley and Black, 1934).

Field Experiment

The experiments were carried out at Akure in the rainforest zone of South
West Nigeria on a sandy loam soil, skeletal, kaolinitic, isohyperthermic oxic paleustalf (Alfisol) or Ferric Luvisol. The surface soil $(0-15 \mathrm{~cm})$ had a $\mathrm{pH}$ (water) of 5.1 , organic matter $0.56 \%, 0.02 \%$ nitrogen, $4.30 \mathrm{mg} / \mathrm{kg}$ extractable $\mathrm{P}$ and $0.11 \mathrm{mmol} / \mathrm{kg}$ exchangeable $\mathrm{Mg}$ (Folorunso, 1999).

The soil had been cropped for 10years. The four field experiments were conducted between April 1998 through July 1999. Twenty agro-industrial biomass treatments, sole and supplemented, were applied to the Amaranthus. Additional treatments included NPK 15-15-15 fertilizer at $400 \mathrm{~kg} / \mathrm{ha}$ and the control (no manure; no fertilizer). The five agro-industrial biomass were wood ash, ground cocoa pod husk, rice bran, brewery spent grain and saw dust.

The materials were applied sole at 6t/ha and each agro-industrial waste was combined with goat, pig and poultry manure at the rate of $3 \mathrm{t} / \mathrm{ha}$. The twenty two (22) treatments were replicated four times on each of the four consecutive amaranthus crops at the same time using randomized complete block design. The size of each of the 88 plots was $16 \mathrm{~cm}^{2}$ $(4 \mathrm{mx} 4 \mathrm{~m})$ and the soils were ploughed and harrowed to maintain good tilth for the amaranthus crops. The sole and supplemented residues and NPK fertilizer were incorporated into the soil seven days before planting.

Seeds of amaranthus (NHAC-35) were hand drilled in rows that were $30 \mathrm{~cm}$ apart (13 rows per plots) at the rate of 7.5 $\mathrm{k} / \mathrm{ha}$. Seed were mixed with equal volume of sand for even spreading. At 10days after planting, seedlings were thinned to a population of 535,332 plants per hectare (212 plants per plot). Vetox 85 at the rate of $28 \mathrm{~g}$ a.i in $9 \mathrm{~L}$ of water was applied at second and fourth weeks after planting.

At 48 days after planting, the plants were harvested in each plot for the determination of the seed parameters. The fresh inflorensce were packed into 
labeled envelopes and oven-dried at $70^{\circ} \mathrm{C}$ for 2 days and the shaft of the inflorescence was removed to get the seed yield. The seed yield of amaranthus were milled into powdered forms, samples were taken, dry ashed at $450^{\circ} \mathrm{C}$ using muffle furnace for 6 hours. The nitrogen content was determined using Kjedahl method (Jackson, 1964), ash and crude protein were determined as described by (A.O.A.C., 1970).

\section{Statistical Analysis}

The data for amaranthus seeds nitrogen, ash and crude protein contents for each of the four crops were presented. They were subjected to ANOVA F-test and their levels of significance were determined for the sole and supplemented manure treatments using Duncan's Multiple Range Test (DMRT) at 5\% level.

\section{Results and Discussion}

Table 1 presents the chemical composition of the agro-industrial biomass used for the cultivation of amaranthus. Among the agroindustrial biomass, the wood ash had the best nutrient status with regards to C, N, K, Ca, Mg, Fe, Mn, Cu and Zn. Wood ash and cocoa husk are relatively high in $\mathrm{K}$, $\mathrm{Ca}$, and $\mathrm{Mg}$ while the spent grain is also high in available $\mathrm{P}, \mathrm{K}$ and $\mathrm{Mg}$. Generally, the saw dust had the highest $\mathrm{C} / \mathrm{N}$ ratio. For the animal manures used for amending the agro-industrial biomass, poultry manure had the highest values of organic C, N, P, Ca, Fe and Mn compared with pig and goat manures.

Effect of agro-industrial biomass on amaranthus seed chemical composition

The data of amaranthus seed $\mathrm{N}$ (Table 2), crude protein (Table 3) and ash (Table 4) for four crops of amaranthus under different agro-industrial biomass are presented. The sole and supplemented agro-industrial biomass increased significantly $(\mathrm{P}<0.05)$ the amaranthus seed $\mathrm{N}$, ash contents and crude protein relative to the control treatment.

The amendment of wood ash, rice bran, spent grain and saw dust did consistently increase seed $\mathrm{N}$ and crude protein of amaranthus except in cocoa husk treatment where the sole form of cocoa husk gave better seed $\mathrm{N}$ and crude protein than the amended forms with pig, goat and poultry manure. The sole and supplemented agro-industrial biomass had higher values of amaranthus seed ash, than NPK fertilizer but the reverse was the case for seed $\mathrm{N}$.

Cocoa husk treatment had the best value of seed $\mathrm{N}$ followed by wood ash, spent grain, saw dust and rice bran respectively. Spent grain also gave the highest value of amaranthus seed ash followed by wood ash, cocoa husk, rice bran and saw dust respectively. The amaranthus seed ash also increased with the application of the agro-industrial biomass from crop 1 to 4 except for sole and supplemented spent grain and saw dust which increased up till third crop and then dropped at $4^{\text {th }}$ crop.

The seed $\mathrm{N}$ and crude protein also increased with the number of sole and supplemented wood ash, cocoa husk, spent grain and saw dust applications but the seed $\mathrm{N}$ of amaranthus dropped after the second application of ordinary and supplemented rice bran.

The agro-industrial biomass such as wood ash, rice bran, cocoa husk, spent grain and saw dust are having lower plant nutrients such as $\mathrm{N}$ and $\mathrm{P}$ compared to animal manures such as poultry, pig and goat manure, hence, the plant residues have high $\mathrm{C} / \mathrm{N}$ ratio and are excepted to decompose more slowly. Thus, a combination of the animal manure and plant residues are excepted to improve the effectiveness of he latter as source of plant nutrients. 
Rice bran and saw dust have relatively high $\mathrm{C} / \mathrm{N}$ compared with cocoa husk, wood ash and spent grain. Therefore, they are excepted to be more resistant to decomposition and less efficient in returning plant nutrients for crop use. Of all the five plant residues; cocoa husk, wood ash and spent grain had relatively high $\mathrm{N}, \mathrm{P}, \mathrm{k}, \mathrm{Ca}$ and $\mathrm{Mg}$ contents and were more effective in improving amaranthus seed $\mathrm{N}$, ash and crude protein than saw dust and rice bran.

The generally low status of seed $\mathrm{N}$, ash and crude protein recorded for the control treatment might be traced to the initial poor nutrient status of the soils and continuous cultivation. The observation corroborates the importance of fertilizer use and application of plant residues to the enhancement of crop productivity in the tropics and this was supported by Agboola (1982) who reported poor crop growth and yield responses in soils not fertilized. The effectiveness of wood ash, spent grain, rice bran, saw dust in improving seed $\mathrm{N}$, ash and crude protein of amaranthus when mixed with animal manures can be adduced to enhancement of their degradation rate by the manure with lower $\mathrm{C} / \mathrm{N}$. However, the processing of the residues before application should have further enhanced their decomposition and rate of nutrient release to the soil. This observation was in agreement with the views of Olayinka (1990) who reported that the organically amended saw dust with dairy manure increased the seed yield of maize, soil $\mathrm{pH}, \mathrm{K}, \mathrm{Ca}$ and $\mathrm{Mg}$ more than the ordinary form of saw dust. He stated further that decomposed forms of these organic residues released nutrients faster to crops than un-decomposed or non processed forms when applied to soils.

The better performance of amaranthus seed $\mathrm{N}$ under cocoa husk (sole) than the amended forms with pig, poultry and goat manures might be adduced to the fact that among the five plant residues, cocoa husk had the least $\mathrm{C} / \mathrm{N}$ ratio which implies that it decomposed faster and makes its nutrients more easily available compared with spent grain, rice bran and saw dust.

Cocoa husk has the highest available $\mathrm{P}$ and better values of $\mathrm{N}, \mathrm{K}, \mathrm{Ca}, \mathrm{Mg}, \mathrm{Fe}$, $\mathrm{Cu}, \mathrm{Zn}$ and $\mathrm{Mn}$ than spent grain, rice bran and saw dust. Cocoa husk has been found to be a good source of $\mathrm{N}$ and $\mathrm{K}$ for maize (Adu-Dapaah et al., 1994).

Sawdust and rice bran respectively were least efficient in the improvement of amaranthus seed $\mathrm{N}$, ash and crude protein. This is consistent with the fact that both saw dust and rice bran had the least N, P, K, Ca, Mg, Fe, Mn, Cu and Zn contents (Table 1 ). This observation was consistent with the findings of MoyinJesu (2003) which reported that saw dust and rice bran gave the least values of amaranthus leaf $\mathrm{N}, \mathrm{K}, \mathrm{Ca}$, ash, $\mathrm{P}$ and $\mathrm{Mg}$ contents and growth parameters compared to other materials and wood ash treatments.

In-addition, these two materials had the highest $\mathrm{C}: \mathrm{N}$ values which would have made them more resistant to degradation and their nutrients made more slowly available than wood ash, cocoa husk and spent grain. Moyin-Jesu and Atoyosoye (2002) reported that rice bran had relatively low $\mathrm{C}, \mathrm{N}, \mathrm{Ca}, \mathrm{Mg}$ and $\mathrm{Zn}$ contents and a high $\mathrm{C} / \mathrm{N}$ ratio of $1: 23$ which made it more resistant to degradation and this affected the growth parameters, leaf chemical composition of cocoa seedlings.

The better ash content of amaranthus seeds in the sole and supplemented forms of the agro-industrial biomass than NPK treatments could be explained by the fact that they contained higher values of $\mathrm{K}$, $\mathrm{Ca}, \mathrm{Mg}, \mathrm{Na}, \mathrm{Fe}, \mathrm{Mn}, \mathrm{Zn}$ and $\mathrm{Cu}$ than the NPK fertilizer. This observation was in line with the findings of Moyin-Jesu and Charles (2003b) who reported better performances of oil palm leaf $\mathrm{P}, \mathrm{K}, \mathrm{Ca}$, $\mathrm{Mg}$ and growth parameters in wood ash sole and supplemented with goat dung, pig dung and poultry manure than NPK treatment. 
The better values of seed $\mathrm{N}$ in NPK fertilizer than the sole and amended forms of agro-industrial biomass could be due to the fact that N in NPK fertilizer is in inorganic form and is expected to be more readily available than those supplied by organic source. Nitrogen is known to be mainly responsible for plant growth and protein synthesis (Ojeniyi,
1984) and it will be useful in human nutrition especially the biscuits products baked from the amaranthus seeds. This observation agreed with the views of Babalola (1999) who reported the evaluation of five grain amaranth (Amaranthus cruentus L) varieties for biscuits making and other product.

Table 1. Chemical Composition of the organic materials use for the experiment.

\begin{tabular}{|c|c|c|c|c|c|c|c|c|c|c|c|}
\hline Treatments & $\mathrm{C}$ & $\mathbf{N}$ & C:N & $\mathbf{P}$ & $\mathbf{C a}$ & $\mathbf{K}$ & Mg & $\mathbf{F e}$ & Mn & $\mathbf{C u}$ & Zn \\
\hline & & & $\%$ & & & $\mathrm{mg} / \mathrm{kg}$ & & & $\mathrm{gg} / \mathrm{kg}$ & & \\
\hline Cocoa husk & 16 & 1.44 & 11.11 & 100 & 9.34 & 20.60 & 7.1 & 50.4 & 8.4 & 0.55 & 1.77 \\
\hline Woodash & 18 & 1.53 & 11.80 & 86 & 9.40 & 23.00 & 8.5 & 65.5 & 11.9 & 0.66 & 1.88 \\
\hline Spent grain & 10 & 0.78 & 12.80 & 56 & 0.13 & 7.90 & 3.1 & 3.4 & 1.0 & 0.10 & 0.70 \\
\hline Rice bran & 14 & 0.60 & 23.30 & 76 & 0.12 & 7.90 & 1.8 & 6.3 & 1.8 & 0.18 & 0.50 \\
\hline Sawdust & 8 & 0.42 & 19.00 & 110 & 0.10 & 5.10 & 1.3 & 4.0 & 1.7 & 0.16 & 0.40 \\
\hline Poultry manure & 30 & 4.33 & 6.93 & 385 & 3.20 & 9.72 & 4.1 & 37.9 & 1.7 & 0.15 & 1.26 \\
\hline Goat manure & 20 & 2.52 & 7.93 & 168 & 2.90 & 9.97 & 4.5 & 34.5 & 1.6 & 0.16 & 1.30 \\
\hline Pig manure & 25 & 3.72 & 6.72 & 312 & 3.10 & 14.45 & 4.8 & 34.0 & 1.6 & 0.17 & 1.34 \\
\hline
\end{tabular}

Table 2. The effect of plant residues plus manure on \% seed nitrogen under the four crops of Amaranthus.

\begin{tabular}{llllll}
\hline Treatments & 1st & 2nd & 3rd & 4th & Mean \pm SEM \\
\hline Control & $0.02 \mathrm{a}$ & $0.03 \mathrm{a}$ & $0.07 \mathrm{a}$ & $0.03 \mathrm{a}$ & $0.38 \mathrm{a} \pm 0.15$ \\
NPK 15-15-15 & $2.78 \mathrm{o}$ & $3.57 \mathrm{u}$ & $4.22 \mathrm{t}$ & $4.33 \mathrm{t}$ & $3.73 \mathrm{r} \pm 0.84$ \\
Wood ash (sole) & $2.52 \mathrm{k}$ & $2.86 \mathrm{k}$ & $3.57 \mathrm{r}$ & $3.71 \mathrm{n}$ & $3.17 \mathrm{~m} \pm 0.75$ \\
Wood ash +Goat dung & $2.58 \mathrm{~lm}$ & $3.14 \mathrm{q}$ & $3.31 \mathrm{kl}$ & $3.82 \mathrm{o}$ & $3.21 \mathrm{n} \pm 0.71$ \\
Wood ash +Pig dung & $2.36 \mathrm{~g}$ & $3.15 \mathrm{qr}$ & $3.56 \mathrm{q}$ & $3.83 \mathrm{op}$ & $3.22 \mathrm{o} \pm 0.8$ \\
Wood ash +Poultry manure & $2.53 \mathrm{kl}$ & $3.25 \mathrm{qr}$ & $3.56 \mathrm{q}$ & $3.95 \mathrm{qr}$ & $3.23 \mathrm{op} \pm 0.75$ \\
Cocoa husk (sole) & $2.63 \mathrm{mn}$ & $3.26 \mathrm{st}$ & $3.85 \mathrm{~s}$ & $3.92 \mathrm{q}$ & $3.41 \mathrm{pq} \pm 0.77$ \\
Cocoa husk +Goat dung & $2.42 \mathrm{ghi}$ & $2.87 \mathrm{kl}$ & $3.40 \mathrm{p}$ & $3.50 \mathrm{~m}$ & $3.05 \mathrm{k} \pm 0.71$ \\
Cocoa husk +Pig dung & $2.38 \mathrm{gh}$ & $2.75 \mathrm{j}$ & $3.26 \mathrm{no}$ & $3.34 \mathrm{k}$ & $2.93 \mathrm{ij} \pm 0.67$ \\
Cocoa husk +Poultry manure & $2.40 \mathrm{gi}$ & $2.95 \mathrm{op}$ & $3.31 \mathrm{k}$ & $3.59 \mathrm{n}$ & $3.06 \mathrm{k} \pm 0.72$ \\
Rice bran (sole) & $0.13 \mathrm{~b}$ & $0.17 \mathrm{~b}$ & $0.12 \mathrm{~b}$ & $0.13 \mathrm{~b}$ & $0.14 \mathrm{~b} \pm 0.15$ \\
Rice bran +Goat dung & $0.14 \mathrm{~cd}$ & $0.18 \mathrm{c}$ & $0.13 \mathrm{bc}$ & $0.16 \mathrm{e}$ & $0.15 \mathrm{c} \pm 0.13$ \\
Rice bran +Pig dung & $0.14 \mathrm{~cd}$ & $0.19 \mathrm{~d}$ & $0.14 \mathrm{~d}$ & $0.15 \mathrm{~d}$ & $0.155 \mathrm{c} \pm 0.15$ \\
Rice bran +Poultry manure & $0.14 \mathrm{~cd}$ & $0.18 \mathrm{c}$ & $0.13 \mathrm{bc}$ & $0.14 \mathrm{c}$ & $0.147 \mathrm{~b} \pm 0.15$ \\
Spent grain (sole) & $1.41 \mathrm{f}$ & $1.86 \mathrm{hi}$ & $1.39 \mathrm{~d}$ & $1.49 \mathrm{f}$ & $1.54 \mathrm{f} \pm 0.47$ \\
Spent grain +Goat dung & $2.37 \mathrm{~g}$ & $2.73 \mathrm{j}$ & $3.23 \mathrm{f}$ & $3.33 \mathrm{k}$ & $2.91 \mathrm{~h} \pm 0.66$ \\
Spent grain +Pig dung & $2.44 \mathrm{hij}$ & $2.90 \mathrm{n}$ & $3.42 \mathrm{p}$ & $4.18 \mathrm{~s}$ & $3.2 \mathrm{op} \pm 0.86$ \\
Spent grain +Poultry manure & $2.44 \mathrm{hij}$ & $2.77 \mathrm{j}$ & $3.29 \mathrm{ij}$ & $3.39 \mathrm{l}$ & $2.97 \mathrm{l} \pm 0.658$ \\
Saw dust (sole) & $0.44 \mathrm{e}$ & $0.87 \mathrm{e}$ & $1.41 \mathrm{~d}$ & $1.50 \mathrm{f}$ & $1.05 \mathrm{~d} \pm 0.70$ \\
Saw dust +Goat dung & $1.40 \mathrm{f}$ & $1.78 \mathrm{f}$ & $1.91 \mathrm{e}$ & $2.40 \mathrm{~g}$ & $1.87 \mathrm{e} \pm 0.64$ \\
Saw dust +Pig dung & $1.39 \mathrm{f}$ & $1.79 \mathrm{fg}$ & $1.98 \mathrm{ef}$ & $2.49 \mathrm{j}$ & $1.91 \mathrm{f} \pm 0.67$ \\
Saw dust +Poultry manure & $1.40 \mathrm{f}$ & $1.79 \mathrm{fg}$ & $2.30 \mathrm{gh}$ & $2.45 \mathrm{i}$ & $1.98 \mathrm{~g} \pm 0.69$ \\
\hline
\end{tabular}

Treatment means within each group or column followed by the same letters are not significantly different from each other using DMRT at the 5\% level. 
Emir. J. Food Agric. 2007. 19 (1): 13-21

http://www.cfa.uaeu.ac.ae/research/ejfa.htm

Table 3. The effect of agro-industrial biomass on \% crude protein under four crops of Amaranthus.

\begin{tabular}{|c|c|c|c|c|c|}
\hline Treatments & 1st & 2nd & 3rd & 4th & Mean + SEM \\
\hline Control (No fertilizer) & $0.15 \mathrm{a}$ & $0.16 a$ & $0.43 a$ & $0.20 \mathrm{a}$ & $0.32 \mathrm{a} \pm 0.36$ \\
\hline NPK 15-15-15 & $17.38 \mathrm{~h}$ & $22.13 j$ & 26.38j & $27.06 \mathrm{~m}$ & $23.28 \mathrm{k} \pm 2.11$ \\
\hline Wood ash (sole) & $15.75 \mathrm{f}$ & 17.88ef & $22.33 \mathrm{~h}$ & $23.19 \mathrm{i}$ & $19.79 \mathrm{~g} \pm 1.88$ \\
\hline Wood ash +Goat dung & $16.13 f g$ & 19.63h & 20.70ef & $23.88 j$ & $20.09 h \pm 1.78$ \\
\hline Wood ash +Pig dung & $14.75 \mathrm{e}$ & 19.69h & $20.26 \mathrm{~h}$ & $23.94 j$ & $20.16 \mathrm{~h} \pm 2.0$ \\
\hline Wood ash +Poultry dung & $15.18 f$ & $20.31 \mathrm{i}$ & $22.26 \mathrm{~h}$ & $24.69 \mathrm{k}$ & $20.77 i+1.93$ \\
\hline Cocoa husk (sole) & $16.44 \mathrm{~g}$ & $20.38 \mathrm{i}$ & $24.05 i$ & $24.50 \mathrm{k}$ & $21.34 j \pm 1.94$ \\
\hline Cocoa husk +Goat dung & 15.13ef & $17.94 \mathrm{ef}$ & $21.26 f g$ & $21.88 \mathrm{~g}$ & $19.05 \mathrm{ef} \pm 1.77$ \\
\hline Cocoa husk +Pig dung & $14.88 \mathrm{e}$ & $17.19 \mathrm{e}$ & $20.35 \mathrm{e}$ & $20.88 \mathrm{f}$ & $18.33 \mathrm{e} \pm 1.67$ \\
\hline Cocoa husk + Poultry manure & 15.00ef & $18.44 f g$ & 20.63ef & $22.44 \mathrm{~h}$ & $19.13 f \pm 1.79$ \\
\hline Rice bran (sole) & $0.83 b$ & $1.08 \mathrm{~b}$ & $0.77 \mathrm{~b}$ & $0.84 b$ & $0.88 \mathrm{~b} \pm 0.37$ \\
\hline Rice bran + Goat dung & $0.89 b$ & $1.11 \mathrm{~b}$ & $0.81 b$ & $0.99 b$ & $0.95 b \pm 0.36$ \\
\hline Rice bran +Pig dung & $0.89 b$ & $1.16 \mathrm{~b}$ & $0.86 b$ & $0.94 b$ & $0.96 b \pm 0.368$ \\
\hline Rice bran +Poultry manure & $0.88 \mathrm{~b}$ & $1.13 b$ & $0.83 \mathrm{~b}$ & $0.87 b$ & $0.93 b \pm 0.37$ \\
\hline Spent grain (sole) & $1.81 \mathrm{~b}$ & $11.62 d$ & 8.71c & 9.31c & $7.61 \mathrm{~d} \pm 2.17$ \\
\hline Spent grain + Goat dung & $14.81 \mathrm{e}$ & $17.06 \mathrm{e}$ & $20.16 \mathrm{e}$ & $20.81 f$ & $18.21 \mathrm{e} \pm 1.67$ \\
\hline Spent grain +Pig dung & $15.25 \mathrm{efj}$ & $18.13 f$ & $21.40 \mathrm{e}$ & $26.13 \mathrm{i}$ & $20.23 h+4.49$ \\
\hline Spent grain + Poultry manure & $15.25 \mathrm{ef}$ & $17.31 \mathrm{e}$ & $20.54 \mathrm{e}$ & $21.19 f$ & $18.57 \mathrm{e}+4.30$ \\
\hline Saw dust (sole) & $2.75 c$ & $5.44 \mathrm{c}$ & $8.79 \mathrm{c}$ & $9.38 c$ & $6.59 c \pm 1.76$ \\
\hline Saw dust +Goat dung & $8.75 f$ & $11.12 d$ & $11.95 \mathrm{~d}$ & $15.00 \mathrm{~d}$ & $11.71 \mathrm{~d} \pm 1.60$ \\
\hline Saw dust +Pig dung & 8.69d & 11.19d & 12.39d & 15.56de & $11.96 \mathrm{~d} \pm 1.69$ \\
\hline Saw dust + Poultry manure & $8.75 \mathrm{~d}$ & $11.19 \mathrm{~d}$ & 14.31de & $15.31 d$ & $12.39 d+1.73$ \\
\hline
\end{tabular}

Treatment means within each group or column followed by the same letters are not significantly different from each other using DMRT at the 5\% level. 
Table 4. The effect of plant residues plus manure on \% seed nitrogen under the four crops of Amaranthus.

\begin{tabular}{lccccc}
\hline Treatments & 1st & 2nd & 3rd & 4th & Mean \pm SEM \\
\hline Control & $1.55 \mathrm{a}$ & $1.35 \mathrm{a}$ & $1.63 \mathrm{a}$ & $1.39 \mathrm{a}$ & $1.48 \mathrm{a} \pm 0.36$ \\
NPK 15-15-15 & $7.32 \mathrm{k}$ & $7.30 \mathrm{l}$ & $6.17 \mathrm{i}$ & $7.32 \mathrm{l}$ & $7.03 \mathrm{ij} \pm 0.76$ \\
Wood ash (sole) & $10.15 \mathrm{q}$ & $9.11 \mathrm{o}$ & $11.73 \mathrm{~s}$ & $9.19 \mathrm{n}$ & $10.04 \mathrm{p} \pm 1.1$ \\
Wood ash +Goat dung & $5.10 \mathrm{e}$ & $5.63 \mathrm{f}$ & $3.90 \mathrm{~b}$ & $5.10 \mathrm{e}$ & $4.86 \mathrm{bc} \pm 0.94$ \\
Wood ash +Pig dung & $10.62 \mathrm{r}$ & 10.00 & $8.40 \mathrm{o}$ & $10.62 \mathrm{q}$ & $9.91 \mathrm{o} \pm 1.02$ \\
Wood ash +Poultry dung & $8.67 \mathrm{n}$ & $9.14 \mathrm{p}$ & $7.81 \mathrm{~m}$ & $8.67 \mathrm{~m}$ & $8.57 \mathrm{l} \pm 0.74$ \\
Cocoa husk (sole) & $6.66 \mathrm{hi}$ & $7.30 \mathrm{l}$ & $5.11 \mathrm{f}$ & $6.67 \mathrm{l}$ & $6.44 \mathrm{~g} \pm 0.97$ \\
Cocoa husk +Goat dung & $7.02 \mathrm{j}$ & $6.93 \mathrm{j}$ & $6.59 \mathrm{jk}$ & $6.88 \mathrm{jk}$ & $6.85 \mathrm{gh} \pm 0.43$ \\
Cocoa husk +Pig dung & $5.62 \mathrm{f}$ & $5.53 \mathrm{~h}$ & $5.43 \mathrm{~g}$ & $5.58 \mathrm{~h}$ & $5.54 \mathrm{~d} \pm 0.29$ \\
Cocoa husk +Poultry manure & $8.91 \mathrm{o}$ & $8.84 \mathrm{n}$ & $8.56 \mathrm{p}$ & $9.93 \mathrm{o}$ & $9.06 \mathrm{mn} \pm 0.77$ \\
Rice bran (sole) & $6.65 \mathrm{~h}$ & $5.96 \mathrm{~g}$ & $5.85 \mathrm{~h}$ & $5.28 \mathrm{fg}$ & $5.93 \mathrm{def} \pm 0.75$ \\
Rice bran +Goat dung & $4.85 \mathrm{~d}$ & $4.92 \mathrm{c}$ & $4.58 \mathrm{~cd}$ & $4.94 \mathrm{~d}$ & $4.82 \mathrm{bc} \pm 0.4$ \\
Rice bran +Pig dung & $7.41 \mathrm{klm}$ & $6.46 \mathrm{l}$ & $7.04 \mathrm{l}$ & $6.84 \mathrm{j}$ & $6.94 \mathrm{ghi} \pm 0.63$ \\
Rice bran +Poultry manure & $9.81 \mathrm{p}$ & 8.53 & $8.31 \mathrm{n}$ & $9.19 \mathrm{n}$ & $8.96 \mathrm{~m} \pm 0.82$ \\
Spent grain (sole) & $10.86 \mathrm{~s}$ & $9.49 \mathrm{q}$ & $11.26 \mathrm{r}$ & $10.15 \mathrm{op}$ & $10.44 \mathrm{pq} \pm 0.88$ \\
Spent grain +Goat dung & $15.34 \mathrm{u}$ & 15.21 & $16.04 \mathrm{u}$ & $15.27 \mathrm{~s}$ & $15.46 \mathrm{~s} \pm 0.62$ \\
Spent grain +Pig dung & $16.71 \mathrm{v}$ & 16.50 & $16.09 \mathrm{uv}$ & $16.72 \mathrm{t}$ & $16.50 \mathrm{t} \pm 0.54$ \\
Spent grain +Poultry manure & $12.34 \mathrm{t}$ & 14.61 & $14.71 \mathrm{t}$ & $14.47 \mathrm{t}$ & $14.03 \mathrm{r} \pm 1.06$ \\
Saw dust (sole) & $5.87 \mathrm{~g}$ & $5.28 \mathrm{~d}$ & $6.53 \mathrm{j}$ & $5.18 \mathrm{ef}$ & $5.71 \mathrm{de} \pm 0.79$ \\
Saw dust +Goat dung & $7.36 \mathrm{kl}$ & $7.00 \mathrm{k}$ & $8.56 \mathrm{q}$ & $6.82 \mathrm{l}$ & $7.46 \mathrm{jk} \pm 0.88$ \\
Saw dust +Pig dung & $4.45 \mathrm{~b}$ & $5.44 \mathrm{e}$ & $4.86 \mathrm{e}$ & $4.69 \mathrm{c}$ & $4.86 \mathrm{bc} \pm 0.65$ \\
Saw dust +Poultry manure & $4.75 \mathrm{bc}$ & $4.47 \mathrm{~b}$ & $4.56 \mathrm{c}$ & $4.55 \mathrm{~b}$ & $4.58 \mathrm{~b} \pm 0.34$ \\
\hline Tratme means with & & &
\end{tabular}

Treatment means within each group or column followed by the same letters are not significantly different from each other using DMRT at the 5\% level.

\section{Conclusion and Recommendation}

Agro-industrial biomass such as wood ash, cocoa husk and spent grain when used in ordinary forms or supplemented with pig, goat and poultry manures are very effective sources of nutrients for enhancing amaranthus seed $\mathrm{N}$, ash and crude protein quality. Saw dust and rice bran were less effective.

It is, therefore, recommended that ordinary form and supplemented agroindustrial biomass such as wood ash, spent grain and cocoa husk applied at 6 t/ha a.i were very useful as fertilizer materials for enhancing the amaranthus seed $\mathrm{N}$, ash and crude protein quality on a lowly fertile soils in the humid tropics. This recommendation is very significant because there is an increasing interest in healthily food life style among food consumers using organic fertilizers as against the use of NPK fertilizers

\section{References}

Adebayo, O. and J. Akoun. 2002. Effect of organic manure and spacing on the yield and yield components of Amaranthus cruentus: Proceedings of the 20th Annual Conference of Horticultural Society of Nigeria held 
at National Horticultural Research Institute (NIHORT) Auditorium Ibadan, pp. 30-32.

Adu-Dapaah, H. K., J. Cobbina and E. O. Asare. 1994. Effect of Cocoa pod ash on the growth of maize. Journal of Agric. Science Cambridge 132:31-33.

Agboola, A. A. 1982. Soil Testing, Soil fertility and fertilizer use in Nigeria. A paper presented at the first National Seminar in Agricultural Land Resources. Kaduna, Nigeria, pp. 6-8.

A. O. A. C. 1970 . Official method of analysis $12^{\text {th }}$ edition. Association of Official Analytical Chemist, Washington, D. C., U.S.A.

Babalola, A. O. 1999. Biscuit making potentials of grain-amaranthus; Proceedings of $17^{\text {th }}$ Annual Conference, Horticultural Society of Nigeria (HORTSON), Port-Harcourt.

Emede, T. O., U. A. Osaigbovo, R. K. A. Egaharevba and P. Siden. 2002. Effects of Poultry manure on the growth and yield of Amaranthus cruentus L. Proceedings $20^{\text {th }}$ Annual Conference of Horticultural Society of Nigeria held in Port-Harcourt, pp. 23-26.

Folorunso, O. O. 1999. Use of Plant residues for improving soil fertility and yield of okra (Abelmoschus esculentum Moench) and Amaranthus (Amaranthus viridus L) Ph.D Thesis. The Federal University of Technology, Akure, Nigeria.

Jackson, M. L. 1964. Soil Chemical Analysis. Prentice Hall Inc. Englewood Cliffs, N. Y. pp. 86-92.

Moyin-Jesu, E. I. and B. Atoyosoye. 2002. Utilization of Agricultural Wastes for the Growth, Leaf and Soil
Chemical Composition of Cocoa seedlings in the Nursery. Pertanika Journal of Tropical Agric. Sci. 25(1):53-63.

Moyin-Jesu, E. I. and B. Atoyosoye. 2002a. Incorporation of AgroIndustrial Biomass and their Effects on Growth and Nutrient content of Amaranthus. Pertanika Journal of Tropical Agric. Sci. Malaysia 26(1):49-58.

Moyin-Jesu, E. I. and E. F. Charles. 2003b. Raising Oil Palm Seedlings in Urban Cities using Sole and Amended Wood ash and Sawdust Manurial Treatments. Pertanika Journal of Tropical Agric. Sci. Malaysia 26(1):19-25.

Ojeniyi, S. O. 1984. Compound Chemical fertilizers and food crop production: Effects of NPK 15-15-15 fertilizer on pepper, cowpea and maize. Nigeria Journal of Applied Science 2:91-95.

Ojeniyi, S. O. and E. I. Moyin-Jesu. 2000. The Effect of organic fertilizers on the growth and leaf yield of Amaranthus. A paper presented at the $20^{\text {th }}$ Annual Conference of Soil Science Society of Nigeria held at University of Ibadan, Ibadan.

Olayinka, A. 1990. Effects of Poultry manure, corn straw and saw dust on plant growth and soil chemical properties. Plant and soil 86: 47-56.

Oyenuga, V. A. 1968. Nigeria's Food and feeding stuff, their chemistry and nutritive value. pp. 45-70 (3rd Eds) Ibadan, University Press.

Walkley, A and I. A. Black. 1934. An examination of Detagaroff method for determining soil organic acid filtration method. Soil Sci. 37:29-38. 